\title{
EL DIÀLEG COM A FORMA. USOS ANTICS I MODERNS
}

\author{
FRANCESCA MESTRE \\ Universitat de Barcelona \\ fmestre@ub.edu \\ ORCID: 0000-0002-4963-2637
}

\section{RESUM}

És habitual llegir que el diàleg va ser inventat, com a forma escrita, a l'Atenes democràtica i que l'obra de Plató n'és l'origen tant des del punt de vista literari com filosòfic. Després de Plató, a l'antiguitat, la forma continua viva, sovint amb la voluntat de seguir l'autoritat que expressar-se com Plató representava, però no sempre, ja que diàlegs com els de Llucià, per exemple, són igualment celebrats però en realitat tenen ben poca cosa del projecte amb el qual Plató s'hi va posar. El propòsit d'aquesta comunicació és fer un breu repàs dels canvis que experimenta la forma del diàleg a la mateixa antiguitat i veure'n la petja en els diàlegs de Paul Valéry, amb l'objectiu d'escatir quina mena de tradició clàssica comporta la utilització d'aquesta forma.

PARAULES CLAU: diàleg, Sòcrates, Plató, Paul Valéry, prosa francesa, tradició clàssica.

\section{DIALOGUE AS FORM. ANCIENT AND MODERN USES}

\section{ABSTRACT}

We generally agree that dialogue was invented, as a written form, in the democratic Athens and that Plato's dialogues are the origin of this both literary and philosophical frame. After Plato, in antiquity, it continues alive, often trying to follow Plato's authority, but not always, since dialogues such as those of Lucian, for example, are also relevant, even not depending exclusively nor essentially of those by Plato. The purpose of this communication is to review briefly the changes experienced by dialogue all along antiquity and then, skipping to modern literature, to explore classical influence in Paul Valéry's dialogues, in order to show what kind of classical tradition entails his use of this form.

KEYWORDS: dialogue, Socrates, Plato, Paul Valéry, French prose, classical tradition.

El meu desig, en aquesta breu exposició, és, d'una banda tractar un tema sobre el que he treballat i treballo, però que al mateix temps respongui al títol d'aquestes jornades - Tradició Clàssica - i que pugui mínimament agradar al nostre homenatjat, el Dr. Pau Gilabert.

M'interessaré per la forma del diàleg a l'antiguitat, ${ }^{1}$ per la seva evolució o pels seus canvis a la mateixa antiguitat, i acabaré parlant d'un home de lletres del

\footnotetext{
${ }^{1}$ No és, ni de bon tros, la meva intenció fer un estudi aprofundit del diàleg a l'antiguitat, sinó simplement esmentar-ne sumàriament algunes fites al llarg del temps i trobar-ne les coincidències que en sobresurten en un escriptor contemporani que en fa ús. Per a una bibliografia més àmplia sobre el diàleg a l'antiguitat, vegeu Hirzel (1895); Andrieu (1954); Cossutta (2004); Föllinger i Müller (2013).
} 
segle XX que va escriure diàlegs, anomenant-los així, per veure l'ús que en fa i quina relació té amb l'antiguitat aquest ús.

Segurament és una obvietat començar dient que el diàleg, com a forma específica d'escriptura filosòfico-literària, o literàrio-filosòfica, té el seu origen en l'activitat filosòfica de Sòcrates, i sobretot quan aquesta activitat és transmesa per Plató, els diàlegs del qual dominen la història tant del gènere com de la seva recepció - fins al punt que també els que se'n volen allunyar ho fan sempre referint-se al model platònic.

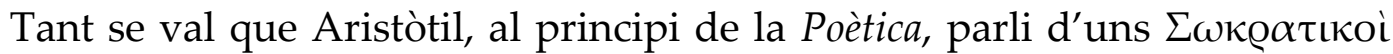
$\lambda$ ó $\gamma \mathrm{O}$ - que alguns tradueixen directament per «diàlegs socràtics» -2 referint-se clarament als gèneres la mimesi dels quals inclou diverses formes i/o personatges: allò que normalment s'entén amb aquesta denominació, doncs, és associat amb una mena de representació de les converses de Sòcrates, probablement posades per escrit per algun dels membres del seu cercle, i on el propi Sòcrates és el o un dels principals interlocutors.

Aquest camí és potser el que marca el domini de Plató sobre la forma del diàleg, i desemboca, des del punt de vista teòric, en la definició, sorgida dels cercles platònics i neo-platònics, que en fa Diògenes Laerci a les seves Vides $i$ doctrines dels filòsofs més il-lustres, el qual, després d'esmentar que alguns diuen que el primer en fer servir diàlegs fou Zenó d'Elea o, segons d'altres, Alaxàmenes de Teos, diu el següent:

Segons el meu parer, però, és Plató que, pel fet de definir la perfecció d'aquesta forma, amb justícia, ha d'endur-se'n el primer premi tant per la bellesa com per la invenció. ${ }^{3}$

I una mica més avall defineix:

El diàleg és un discurs que consta de preguntes i de respostes, sobre algun tema de filòsofs o de polítics, amb la caracterització idònia dels personatges que hi intervenen i l'expressió verbal del seus raonaments. La dialèctica és un art de les paraules mitjançant la qual refutem o confirmem a partir de les preguntes i respostes dels que dialoguen. ${ }^{4}$

La definició de Diògenes Laerci, per tant, tot i deixar clares quines són les prioritats d'allò que anomenem 'diàleg' - es tracta d'un intercanvi de preguntes i respostes amb rols determinats, de tema seriós (filosòfic o polític), és a dir, una literatura d'idees més que no pas la reproducció d'una conversa-, no s'està

${ }^{2}$ Arist. Po. 1447b; així tradueix Xavier Riu en la recent edició de la Poètica a la FBM (Barcelona 2017); sobre els sokratikoi logoi vegeu Ford (2008).

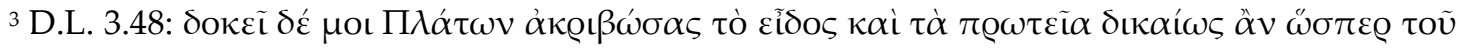

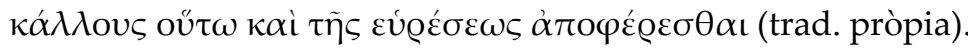

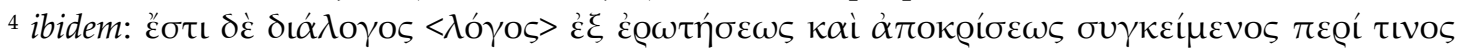

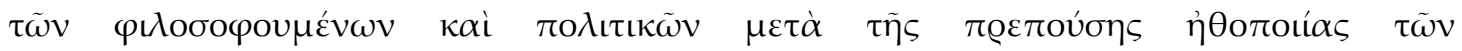

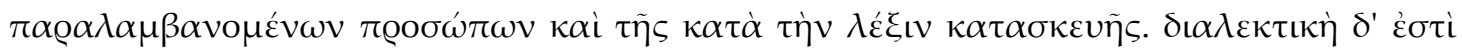

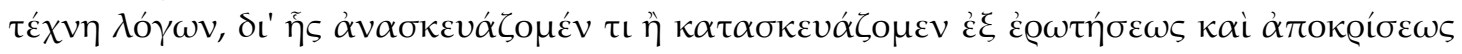
$\tau \tilde{\omega} \nu \pi \varrho 0 \sigma \delta \iota \alpha \lambda \varepsilon \gamma \circ \mu \varepsilon \dot{v} \nu \omega \nu$ (trad. pròpia). 
d'esmentar la importància que el context retòric hi juga: recursos com el de l'ethopoiia (caracterització dels personatges), la kataskeue i l'anaskeue (confirmació i refutació), que són fins i tot els noms d'exercicis preparatoris de l'escola retòrica (progymnasmata), apareixen a la definició, donant a entendre que aquests aspectes, encara que potser subsidiaris del tema principal, de les idees i les tesis exposades, tenen també una certa rellevància; i, al costat dels recursos retòrics, allò que la performance del diàleg comporta: els aspectes dramàtics, tant de personatges com d'escenografia.

Aquesta definició és, com diu encertadament S. Dubel, ${ }^{5}$ totalment finalista, normativa i restrictiva, tant que molts diàlegs del mateix Plató no la complirien - de fet, l'estricte intercanvi de preguntes i respostes va evolucionant en el mateix corpus platònic, i aquest esquema sol ser substituït per intervencions llargues d'algun o alguns interlocutors combinades amb intervencions breus dels altres. És, la de Diògenes Laerci, sens dubte, una normativa de caire escolar, que coincideix força amb les que en fan els autors dels manuals de Progymnasmata.

Per altra banda, quan Diògenes Laerci dona la seva definició de diàleg i del seu origen acomplert en Plató, ho fa oposant-se al que altres diuen: es deu referir, segurament, a Demetri, l'autor del tractat Sobre l'estil, potser d'època hel-lenística

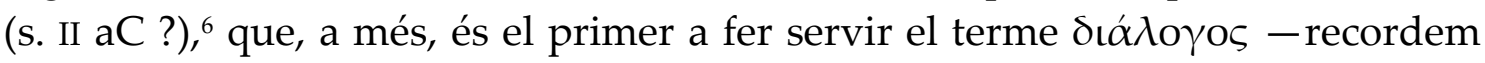
que Aristòtil quan parlava dels socràtics en deia $\lambda o ́ \gamma o \iota-$ i l'aplica a una forma que ve a ser la representació d'una conversa, oposant-la a un altre tipus de conversa que seria l'intercanvi epistolar. Diu així Demetri:

cal que la carta estigui més acuradament treballada que el diàleg, ja que aquest representa la paraula improvisada, mentre l'altra és escrita i és enviada com si fos una mena de regal. ${ }^{7}$

Per tant, segons Demetri, el diàleg, gràcies a aquest marc de conversa espontània, permet moltes variants, que són possibilitats de modelar, per exemple, enunciats morals, elogis o blasmes, interrogacions, etc., sense necessàriament afectar l'autor, que s'amaga darrera la caracterització dels seus personatges.

D'aquestes dues línies - la de Demetri i la de Diògenes Laerci- ens en podem servir instrumentalment per explicar l'evolució del diàleg, tant a la mateixa antiguitat, com fins als nostres dies: la línia que posa més l'èmfasi en l'aspecte de contingut filosòfic que vehicula la forma de l'intercanvi dialogat, i la

\footnotetext{
${ }^{5}$ Dubel (2015: 11).

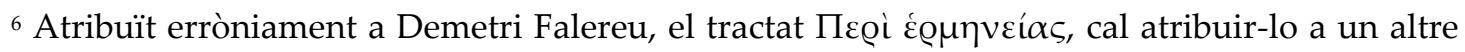
Demetri posterior, el filòsof peripatètic d'època hel-lenística, Demetri d'Alexandria; sobre l'autoria i la identitat de l'autor, vegeu Chiron (2001: 15-32).

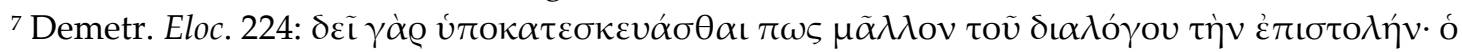

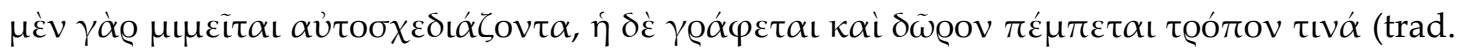
pròpia). Sobre les importants aportacions que el tractat de Demetri forneix sobre el diàleg, vegeu Dubel (2015: 14-19).
} 
que dona prioritat a l'intercanvi mateix, a la conversa espontània, al seu marc més dramàtic, palesant aspectes dels encontorns i dels interlocutors.

La Roma republicana mostra com en el món polític romà es donava una gran importància a la modalitat dialògica per a la formació de l'orador. Ciceró és certament el gran redefinidor de la forma del diàleg a Roma - molt especialment en el De Oratore - : 8 la base dels diàlegs de Ciceró s'arrela clarament en el model platònic, tot i que hi afegeix algunes variants formals. Per exemple, el propi autor hi és present, és un dels interlocutors, cosa que no passa mai en el diàlegs platònics; o bé, Ciceró, gran mestre de la hypotyposis, recrea converses tant de contemporanis com de romans del passat - els exemples més obvis són De senectute o De amicitia. Aquest fet introdueix, necessàriament, elements d'etopeia o prosopopeia que es construien de manera diversa quan els personatges participants de la conversa eren persones estrictament contemporànies. ${ }^{9}$ Tot i aquests canvis, en el cas de Ciceró, el diàleg és vehicle per fer i escriure filosofia en llatí, o fins i tot per reconciliar les pràctiques oratòries amb les filosòfiques. En certa mesura el Diàleg dels oradors de Tàcit li segueix la petja. ${ }^{10}$

La literatura grega d'època romana, per la seva banda, torna a ser el gran moment de la forma 'diàleg', amb un ampli ventall d'exemples. Des de Plutarc, que amb tota evidència, vol recrear el diàleg platònic i ser ell mateix un nou Plató en la faceta d'escriptor - una altra cosa és que ho aconsegueixi-, fins al gran innovador Llucià, o, en l'entremig, uns estadis més de síntesi, tot i que molt originals, com són el casos de Filòstrat al seu Heroic, o, encara diversament, el d'Ateneu. Els Deipnosofistes d'Ateneu, sense teoritzar - com sí que fa Lluciàsobre la forma emprada, mostra una gran creativitat orquestrant una mena de polifonia en la qual els personatges dialoguen entre ells i amb els textos, i la cosa arriba al seu paroxisme quan són directament les cites que dialoguen entre elles. Hi ha fins i tot qui ha dit, potser encertadament, que el d'Ateneu és un centó dialògic. ${ }^{11}$

L'Heroic de Filòstrat, per la seva banda, des del punt de vista formal, té l'encert de plantejar tot el seu programa d'hel-lenitat a través de la creació de dos personatges, un vinyater i un fenici, usant una de les formes d'exercicis retòrics, l'etopeia, i és precisament aquest perfecte ús de l'etopeia dels seus personatges que fa girar tot el diàleg: tot és presentat a través de la conversa entre aquests dos interlocutors i cadascun dels elements que aporta aquesta obra - des de l'autèntica veritat sobre la guerra de Troia, passant pel culte als herois - sorgeix d'allò que la conversa dels dos personatges, caracteritzats adequadament, provoca. ${ }^{12}$

\footnotetext{
8 Vegeu, per una exposició interessant del tema, Giorgio (2012).

${ }^{9}$ Per a la interacció entre realitat i ficció als diàlegs ciceroninans, vegeu Hanchey (2014).

${ }^{10}$ Una bona síntesi n'és Syson (2009).

${ }^{11}$ Sobre diàleg i intertextualitat, vegeu Jacob (2000).

${ }^{12}$ Sobre l'Heroic des del punt de vista formal, vegeu Whitmarsh (2009); Mestre i Gómez (2018).
} 
Pel que fa a Llucià, és cèlebre la seva crítica respecte a la forma emprada per Plató, en els famosos passatges de la Doble acusació, quan Diàleg, que és ell mateix un personatge del diàleg, es queixa i denuncia davant la justícia el rètor siri per tots els canvis que li ha fet experimentar (Bis Acc. 33), l'acusa d'haver-li llevat respectabilitat, d'haver-li tallat les ales i convertit en un ésser comú, i d'haver-lo assimilat a la comèdia, la burla, el iambe i el cinisme, de manera que ha esdevingut una mena de pallasso.

En resposta a aquestes acusacions (Bis Acc. 34), el rètor siri li ve a dir que encara gràcies, que amb la seva intervenció el diàleg ha deixat de ser trist i avorrit, perquè tot i respectat, era desagradable per a la majoria de la gent. En canvi ara, gràcies a ell, toca de peus a terra, somriu i és agradable per a tothom.

S'ha escrit moltíssim sobre la manera d'interpretar aquest intercanvi d'acusacions i de defenses, i de veure com s'aplica a la resta de diàlegs del de Samòsata, tant els minores com els maiores. Per dir-ho ara en poques paraules, Llucià dota la forma del diàleg d'elements evidents de teatralitat, lligats especialment a la comèdia, i en fa un espai de ficció, ideal per vehicular l'humor, la ironia i la sàtira. Un humor, una ironia i una sàtira que posen damunt la taula la tradició de la qual ell mateix és deutor, i, sobretot i especialment, la insistència, equivocada al seu parer, dels seus contemporanis en mantenir-s'hi aferrats com si el món d'avui fos el món d'ahir. Per tant, quan es diu que aquestes paraules són una crítica a Plató crec que l'afirmació no és exacta - al cap i a la fi, hi ha molt de pensament i d'inspiració platònica en els textos de Llucià-, es tracta més aviat d'una crítica a una actitud dels seus contemporanis, dels intel-lectuals de l'imperi, que supleixen la falta de talent emulant matusserament els grans noms del passat. ${ }^{13}$

Fins aquí el panorama, excessivament veloç i altament incomplet, que m'ha vagat de fer dels viaranys pels quals transita la forma del diàleg a l'antiguitat.

Saltem ara a la literatura contemporània. Sens dubte, la forma del diàleg no és ni de bon tros de les més sovintejades; gens pel que fa a l'expressió del pensament filosòfic, i poc, però una mica més, en l'expressió literària.

Un dels pocs exemples que podem trobar són els diàlegs del poeta, assagista i escriptor francès de principis del s. xx Paul Valéry, que, intencionadament, escriu diàlegs i, a més, explica què aporta aquesta forma als seus modes d'expressió. ${ }^{14}$

Em referiré, breument, a títol d'exemple, als tres diàlegs més coneguts de Valéry que són Eupalinos, L'ànima i la dansa, i Diàleg de l'arbre, publicats l'any 1921,

${ }^{13}$ La bibliografia sobre el tema és molt abundant; en faig una petita selecció: Saïd (2015); Camerotto (1998); Mestre (1997).

${ }^{14}$ Val a dir, per altra banda, que els Diàlegs no són, ni de bon tros, la part més estudiada de l'obra de Valéry, no al mateix nivell que la seva poesia o els seus assajos; vegeu, tanmateix, Parisier-Plottel (1960), Duchesne-Guillemin (1972); Laurenti (2006); Laurenti (1973). 
1922 i 1943, respectivament. ${ }^{15}$ Haig de dir, d'entrada, tanmateix, que no és tampoc l'objectiu d'aquest treball entrar a fons sobre el contingut i el pensament que contenen aquestes tres obres, ni tampoc sobre el seu valor literari. M'interessa, però, referir-m'hi a fi d'aportar algun ingredient a la mena tradició clàssica que vehiculen, i explicar les reflexions que el propi Valéry fa de la seva forma dialogada i les circumstàncies que n'envolten la producció.

Eupalinos és un diàleg entre Sòcrates i Fedre, en el qual el primer explica a Sòcrates - que defensa la filosofia per damunt de l'art i de l'arquitectura - els prodigis arquitectònics de l'home que dóna nom a l'obra, i li refereix com l'arquitecte sostè en els seus raonaments que els temples són poiesis i, doncs, l'arquitectura -igual que la música - són el darrer paradigma del treball de l'esperit, del potencial de l'esperit aplicat a la matèria. ${ }^{16}$ Realment, es fa molt difícil de veure en tot això un desig de connectar amb el món grec antic, o de reinterpretar-lo o simplement d'evocar-lo significativament; no així, com veurem, si tenim en compte les condicions concretes en les quals el famós poeta va escriure Eupalinos.

Com moltes altres del mateix autor - no oblidem que Valéry va ser una personalitat no només literària- Eupalinos era una obra d'encàrrec: els arquitectes Louis Suë i André Mare l'hi van demanar com introducció de la monumental edició de Architectures... la présentation d'ouvrages d'architecture, décoration intérieure, peinture, sculpture et gravure, contribuant depuis mil neuf cent quatorze à former le style français, llibre de gran format publicat per la Nouvelle Revue Française el 1921, amb multitud de plànols i de dibuixos, que intentava donar carta de naturalesa, a França, dels Wiener Werkstätte. En aquest llibre s'intentava demostrar les raons matemàtiques inevitables de tota obra arquitectònica i, per tant, l'encàrrec literari també havia de quadrar amb aquest tipus d'exactitud, per la qual cosa havia de tenir, exactament, 115.800 caràcters, ni un més ni un menys.

Aquesta, segons confessa el mateix Valéry, és la raó per la qual creu, en aquell moment, que la forma del diàleg li serà el vehicle més fàcil per poder complir amb una exigència tan concreta: una rèplica més o menys curta o llarga és el recurs òptim per a l'expressió d'un pensament determinat, que pot ser escurçat o allargat segons convingui. ${ }^{17} \mathrm{I}$, és clar, un cop triada la forma del diàleg, l'escriptor troba que donar-li aparença grega és el que escau: posa com a interlocutors Sòcrates i Fedre, i busca un nom, també grec, per a l'arquitecte, Eupalinos, que, com admet el propi escriptor, més que arquitecte era enginyer

${ }_{15}$ D'Eupalinos existeix una traducció en català, i en castellà de tots tres, vegeu Llovet (1983); Arautegui Tamayo (2000) i Serra Arús (2017), respectivament.

${ }^{16}$ Per a un estudi ampli d'aquest diàleg, vegeu l'exhaustiu - tot i que una mica obscur - estudi de Fehr (1960), així com també Bekaert (1994).

${ }_{17}$ Duchesne-Guillemin (1972), 76; vegeu també Cahiers I 197: «c'est la forme qui m'intéresse. Le fond de la pensée n'est rien - et les théories qui n'aboutissent pas à des procédés, lesquels jugent les thèses - ne me font aucun effet» (les cursives són de l'autor). 
- aquest era el nom d'Eupalinos de Mègara que va fer l'aqüeducte subterrani a Samos, sota la tirania de Polícrates,$-{ }^{18}$ però Valéry en fa servir el nom com a gran constructor de temples. Per altra banda, el diàleg té lloc a l'Hades, és, per tant, un 'diàleg dels morts', la qual cosa, com és obvi, fa pensar també en Llucià, a qui, ben segur, Valéry coneixia ni que només fos com el model de Fénélon i Fontenelle. ${ }^{19}$

Res d'això, tanmateix, no sembla tenir gaire importància, ja que és ben curiosa l'explicació afegida de l'autor: mai no he estat a Grècia, ve a dir, i a l'escola era un alumne de grec més aviat mediocre; soc incapaç de llegir Plató en la llengua original, però és que, fins i tot en traducció, el trobo llarg i avorrit. ${ }^{20}$

Malgrat tot, res no li impedeix d'escriure diàlegs que la crítica ha anomenat "platònics», ${ }^{21}$ com és el cas també de l'altre, L'ànima i la dansa, escrit poc després d'Eupalinos, on els interlocutors tornen a ser Sòcrates i Fedre, aquesta vegada acompanyats pel metge Erixímac: tots tres també presents en el Banquet de Plató.

L'ànima i la dansa, per la seva part, es proposa fer del diàleg una mena de ballet i mostrar com es van alternant imatges i idees com a corifeus. ${ }^{22}$ Moltes són, en efecte, les reflexions sobre el pensament que el gran poeta francès compara a la dansa, com quan entén que la filosofia autèntica no és altra cosa que un «art de pensar», de la mateixa manera que la dansa vindria a ser el moviment del cos fet art. ${ }^{23}$ En un i altre cas, però, admira, tant per al filòsof com per al dansaire - així com per altra banda per al cantant, el poeta - aquella part tècnica, mecànica, física i biològica que apropen els objectes a les accions, l'útil a l'inútil, el material a l'immaterial, i en el seu automatisme ateny la perfecció; troba encara altres maneres metafòriques $-\mathrm{i}$ ben singulars - $\mathrm{d}$ 'anomenar aquest fenomen $\mathrm{i}$ aquesta coincidència, per exemple, «estat d'energia lliure», sense guanys ni pèrdues, on

\footnotetext{
18 És esmentat a Hdt. 3.60.

${ }^{19} \mathrm{El}$ cas de Fontenelle, a més, amb els seus Dialogues des morts (1683) és paradigmàtic de la petja llucianesca a la literatura europea a partir del Renaixement, sobre Fontenelle i Llucià vegeu Carruesco i Reig (2010), amb bibliografia.

${ }^{20}$ «Or je lis mal et avec ennui les philosophes - qui sont trop longs et dont la langue m'est antipathique. Si l'on savait combien peu j'ai lu Platon - et en traduction!», Cahiers I 197 (vegeu també I 195-196); o també, més endavant: «Le peu que l'on sait, parfois est plus actif et fécond que le beaucoup (...) L'excessivement peu que je savais de Platon et qui eût tenu en dix ou quinze lignes m’a produit Eupalinos», Cahiers I 283 (les cursives són de l'autor).

${ }^{21}$ Valéry els anomena, en canvi, «dialogues socratiques»: Cahiers I 197.

22 «Mon dialogue sur la danse est une danse dans laquelle tantôt le brillant des images, tantôt le profond des idées sont coryphées, pour s'achever en union», Cahiers I 268.

23 «La vraie philosophie me paraît pouvoir se réduire - ou se confondre - ou s'élever à un art de penser qui soit à la pensée naturelle ce que la gymnastique, la danse, etc. sont à l'usage accidentel et spontané des membres et des forces», Cahiers I 361 ((les cursives són de l'autor); pensament que completa una mica més endavant: «je place dans l'intervalle qui existe entre les actions circonstancielles physiologiques et les actions nées de l'arbitraire et de l'esprit, les actions comme la danse, qui sont apprises, mais qui tendent vers l'automatisme, comme vers leur perfection. Ici la conscience s'évertue à faire l'automatisme final», Cahiers I 1143.
} 
l'extern té un important paper de suport, i tot funciona com una màquina, on cada peça, segons les lleis físiques i de la mecànica, té el seu rol. ${ }^{24}$

Els crítics diuen que l'amistat de Valéry tant amb Debussy com amb el pintor d'escenes de ballet per excel·lència, Edgar Degas, subjau en aquesta mena $\mathrm{d}^{\prime}$ anàlisi dialogada sobre la dansa. ${ }^{25}$

També és curiós de notar que l'hel-lenista Louis Séchan, quan el $1930^{26}$ va publicar el seu llibre sobre la dansa a l'antiguitat, el primer que va fer va ser enviar-n'hi un exemplar a Valéry, de qui havia llegit amb entusiasme el diàleg L'ànima $i$ la dansa. Amb la mateixa humilitat - potser indiferència? - i desimboltura que referint-se a Eupalinos, Valéry va escriure una carta a Séchan agraint-li el regal, però hi afegia que malauradament no coneixia ni Cal-límac, ni Llucià, ni Xenofont, ni res del que diguessin sobre la dansa i que, a més, encara que els hagués llegit tampoc no li haurien servit de res per a allò que ell va voler fer en el seu diàleg. ${ }^{27}$

Una vintena d'anys més tard, quan va ser convidat a parlar a l'Institut de France, per comptes d'un discurs va llegir el seu Diàleg de l'arbre, un entretien aquesta vegada d'uns tals Títir i Lucreci que s'esplaien en discursos poètics dedicats a un arbre. En aquest cas, però, hi havia un antecedent directament relacionat amb el món antic: Valéry, que en llatí devia ser menys mediocre que en grec, tradueix, també per encàrrec, les Bucòliques de Virgili per a la «Société de bibliophiles Scripta et picta». D'aquesta experiència neix el Diàleg de l'arbre, que presenta a l'Institut de France, el 25 d'octubre de 1943, en plena ocupació nazi. ${ }^{28}$ Abans de començar la lectura del diàleg, fa la següent presentació:

Une certaine circonstance - un hasard, puisque le hasard est à la mode - m'ayant fait revenir, il y a quelque temps, aux Bucoliques de Virgile,29 (que je n'avais pas revues, je

\footnotetext{
24 «les choses extérieures jouent un rôle curieux. Elles ne sont plus que parties prévues de ma machine. Le sol pour le danseur, l'arbre que le penseur fixe, où il s'appuie en esprit. Si le sol cède, si l'arbre est abattu, si le mot manque à la marche de la pensée - si la musique s'interrompt - on n'est plus à l'état de grâce - je veux dire à l'état de loi», Cahiers I 1300 (les cursives són de l'autor).

25 «Mais quant à la structure esthétique c'est d'instinct qu'elle se fait. De cette remarque me vient l'idée de musicaliser - que j'ai eue et appliquée autrefois et des ouvrages comme le 1er Léonard et mes dialogues. Il s'agit de composer [...] de vouloir ordonner des parties spécialisées - chacune consacrée à un mode - un mouvement- un registre de mots, un régime de substitutions (rasisonnement, imagerie, sentiment-) et de ménager contrastes, symétries, et les modulations ou les discontinuités!», Cahiers I 315 (les cursives són de l'autor).

${ }^{26}$ Séchan (1930).

27 «Ni Callimaque, ni Lucien, Xénophon, ni la Parthénie ne m’étaient connus; et d'ailleurs ne m'eussent pas servi de grand'chose. Les documents, en général, me gênent plus qu'ils ne me secourent», Lettre à Louis Séchan, août 1930, a Valéry (1957-1960) II 1407-1408; tanmateix, una mica més endavant, en la mateixa carta, admet haver consultat alguns llibres històrics sobre la dansa grega i esmenta concretament el d'Emmanuel (1896).

${ }^{28}$ Vegeu http://www.academie-francaise.fr/le-dialogue-de-larbre (consultat el 30 de maig de 2019).

${ }^{29}$ Es refereix a la seva traducció de les Bucòliques.
} 
l'avoue, depuis bien des années), ce retour au collège m'a inspiré d'écrire, comme un devoir d'écolier, la fantaisie en forme de dialogue pastoral dont je vous lirai quelque partie. Des discours, plus ou moins poétiques, consacrés à la gloire d'un Arbre, s'échangent entre un Tityre et un Lucrèce, dont j'ai pris les noms sans les consulter.

Com veiem, doncs, l'arrelament en la tradició clàssica dels diàlegs de Valéry és més aviat anecdòtic, per no dir decoratiu. Tanmateix, aquests diàlegs són considerats l'obra mestra de la imaginació poètica en prosa de Paul Valéry. L'escriptura seqüencial, discontinua, fragmentària, fracturada i caòtica del diàleg, la seva flexibilitat formal, en una paraula, és idònia per representar l'estructura mental de Paul Valéry - que tan bé queda reflectida en els seus Cahiers - , una estructura dual, fins i tot plural, que ve a ser com parlar-se a un mateix amb dues veus, ${ }^{30}$ o bé expressar el pensament des de fora, com si fos d'un altre, desempallegant-se de tota responsabilitat. ${ }^{31}$ Per tant, el que trobem en els seus diàlegs, més que un intercanvi entre interlocutors és l'oportunitat del seu propi jo d'expressar-se amb més d'una veu, un jo amb diverses màscares, que pot anar canviant de to; $; 2$ o bé, altrament, una via per donar sortida a la seva tendència a quedar-se a part, distanciat:

Cette faculté d'éloignement, que j'ai, du reste, utilisée pour concevoir mieux la relativité que masque le langage et l'habitude. Éloignement = étonnement - recul. Ce qui était toute la vue en devient partie ou cas particulier. ${ }^{33}$

Reflexionant sobre què trobem de les diverses evolucions i redefinicions del diàleg antic en els diàlegs de Valéry, se m'acuden tres qüestions que no desenvoluparé in extenso, però que crec que simplement deixant-les apuntades podré tancar el cercle del que aquí volia exposar.

Per una banda, el més obvi: malgrat totes les facetes i prismes que pren el diàleg després de Plató, el model platònic, ni que sigui simplement formal, de marc, de personatges, continua essent el que preval, almenys en les primeres mostres (Eupalinos, L'ànima $i$ la dansa): com si un diàleg sense Sòcrates no fos

\footnotetext{
30 «Cette étrange propriété d'être deux en un - en contraste avec quoi le désir d'amour - d'être un par deux apparaît complémentaire de la connaissance consciente», Cahiers II 519 (les cursives són de l'autor).

${ }^{31}$ Vegeu Duchesne-Guillemin (1972), que encunya, per al cas de Valéry, el terme «dialoguealibi» i l'explica com segueix: «Ces idées, notons-le, ne sont jamais réellement discutées; sous le couvert de l'alibi, elles se présentent d'une manière péremptoire» (87).

32 «Je pensais, en particulier, aux changements de ton - qui n'existent guère (et encore!) que dans le dialogue dramatique. Mais tout écrit comporte un dialogue dramatique - et il n'est de page où ne se dessinent des contrastes, des variations de champ, des entrées, des dénouements», Cahiers II 1236; i més endavant: «Que j'aimerais écrire - ou plutôt avoir écrit! un dialogue qui s'appellerait Protée - et chaque interlocuteur aurait sa voix, son style - et sa voix mentale. Plusieurs modes de voir, et leur alternance ferait dialogue. N'ai-je pas vu de plusieurs façons et n'aurais-je pu me rencontrer moi-même? - Et cela n'est-il pas arrivé, n'arrive-t-il pas?», Cahiers II 1314 (les cursives són de l'autor).

${ }^{33}$ Cahiers I 220 (les cursives són de l'autor).
} 
realment un diàleg, encara que aquest personatge només sigui un nom. El Diàleg de l'arbre, en canvi, mostra molt més tardana - Valéry mor dos anys després de la seva publicació-, recupera un altre espai, més poètic, més íntimament lligat a la seva pròpia tasca de poeta, el de les Bucòliques i la seva identificació amb Virgili:

Je vois la nature à ma façon. Je pense à ceci, en regardant une grande chèvre dans les oliviers. Elle mordille, bondit. - Virgile- pensé-je. Jamais l'idée de peindre cette chèvre ne me fût venue. Virgile prouve que l'on peut en faire quelque chose. Je la regarde donc. Elle cesse aussitôt - d'être chèvre - et l'olivier cesse d'être olivier. Ici commence moi - c'est-à-dire un regard que je voudrais bien définir. Il y a des arbres, des fleurs, un chien, des chèvres, le soleil, le paysan, et moi, et la mer au loin; et nous tous ensemble convenons que le passé n'existe plus. ${ }^{34}$

En efecte, el poeta es posiciona davant la natura que l'envolta - en concret i en metàfora - igual que Virgili, però amb les seves pròpies referències.

En segon lloc, hi ha un aspecte que és constant en totes les mostres de diàleg de l'antiguitat - llevat dels casos en què Ciceró és un dels interlocutors - : l'autor es separa de la seva obra, és com un narrador que exclou l'autor; es tracta d'una manera que té l'autor d'avançar com a cobert, amagat, deixant aleshores al públic que tregui les seves pròpies conclusions. Les màscares de Valéry, aquesta seva manera d'expressar-se amb més d'una veu, són en opinió meva el que, en realitat, més apropa els seus diàlegs a la forma antiga.

I, en darrer lloc, una qüestió de caire molt menys literari i molt més intel-lectual -i social: Valéry considera l'aportació innegable dels clàssics a la cultura francesa, i de la llengua llatina sobre la francesa en particular, en un moment en el qual es debatia força si aprendre llatí - i eventualment grec- a l'escola servia per a alguna cosa, i les reformes educatives anaven i venien posant i traient el llatí de l'ensenyament secundari. Sense cap mena de dubte Valéry era crític amb el valor que podia aportar, a l'adolescència, l'aprenentatge del grec i del llatí, i el seu aprofitament. Aquestes soles breus sentències - n'hi ha d'altres - ho deixen ben clar: «Le latin, le grec - appréciables à 40 ans», o bé: «Virgile n'est pas un poète. C'est un "texte" ». ${ }^{35}$

Tanmateix, l'intel-lectual que és Paul Valéry, així com el poeta, no amaga que la formació en els clàssics és present en les seves activitats, però hi passa de puntetes, no s'hi involucra, se'n serveix com d'un accessori, però també en fuig, no vol lligams clàssics, és dualment egocèntric, molt influenciat per Mallarmé i un simbolista a la seva manera. El diàleg, per tant, és forma - que practica - i s'ajusta a la dualitat interior que transmet també en la seva poesia, però deixa ben clar que és tot seu i que no pretén inscriure la seva obra en la tradició clàssica.

${ }^{34}$ Cahiers I 97.

${ }^{35}$ Cahiers II 1556 i 1557. 


\section{BIBLIOGRAFIA}

ANDRIEU, J. (1954), Le dialogue antique. Structure et présentation, Paris, Les Belles Lettres.

ARAUtegui TAMAYO, J. L. (2000), Paul Valéry. Eupalinos o el arquitecto; El alma y la danza, Madrid, A. Machado Libros.

BEKAERT, G. (1994), «Le réel du discours. Eupalinos ou l'architecte», OASE, 40, 21-46.

CAmerotto, A. (1998), La metamorfosi della parola. Studi sulla parodia in Luciano di Samosata, Pisa, Istituti editoriali e poligrafici internazionali.

CARruesco, J. I ReIG, M. (2010), «Fontenelle i els Nous diàlegs dels morts: unes Vides paral-leles a la manera de Llucià», a Lucian of Samosata. Greek writer and Roman citizen, Mestre, F. i Gómez, P. (eds.), Barcelona, Publicacions i Edicions UB, 49-61.

CHIRON, P. (2001), Un rhéteur méconnu: Démétrios (Ps.-Démétrios de Phalère): Essai sur les mutations de la théorie du style à l'époque hellénistique, Paris, Vrin.

CossutTA, F. (ed.) (2004), La Dialogue. Introduction à un genre philosophique, Lille, Septentrion.

DUBEL, S. (2015), "Avant-propos: théories et pratiques du dialogue dans l'Antiquité», a Formes et genres du dialogue antique, Dubel, S. i Gotteland, S. (eds.), Bordeaux, Ausonius, 11-23.

DuCHESNE-GuillemiN, J. (1972), «Les dialogues de Paul Valéry», Cahiers de l'Association internationale des études françaises, 24, 75-91.

EMMANUEL, M. (1896), La danse grecque antique d'après les monuments figurés, Paris, Hachette.

FEHR, A. J. A. (1960), Les dialogues antiques de Paul Valéry. Essai d'analyse d'Eupalinos ou l'architecte, Leiden, Universitaire Pers.

FÖllinger, S. I MÜLler, G. M. (eds.) (2013), Der Dialog in der Antike. Formen und Funktionen einer literarischen Gattung zwischen Philosophie, Wissensvermittlung und dramatischer Inszenierung, Berlin, De Gruyter.

FORD, A. (2008), «The beginnings of dialogue: Socratic discourses and fourth-century prose», a The End of Dialogue in Antiquity, Goldhill, S. (ed.), Cambridge-New York, Cambridge University Press, 29-44.

GIORGIO, J.-P. D. (2012), «Defining dialogue in ancient Rome: Cicero's De oratore, drama and the notion of everyday conversation», Language and Dialogue, 2.1., 105-121.

HANCHEY, D. (2014), «Days of future passed: fiction forming fact in Cicero's dialogues», The Classical Journal, 110.1, 61-75.

HIRZEL, R. (1895), Der Dialog. Ein literarhistorischer Versuch, Leipzig, S. Hirzel.

JACOB, C. (2000), "Athenaeus the Librarian», a Athenaeus and his World, Wilkins, J. i Braund, D. (eds.), Exeter, University of Exeter Press, 85-110.

LAUReNTI, H. (1973), Paul Valéry et le théâtre, Paris, Gallimard.

LAURENTI, H. (2006), «L'Imaginaire théâtral de Paul Valéry», a Paul Valéry 12: Image, imagination, imaginaire autour de Valéry, Sang-Tai, K. (ed.), Caen, Minard.

Llovet, J. (1983), Paul Valéry. Eupalinos o l'arquitecte, Barcelona, Quaderns Crema.

Mestre, F. I GómeZ, P. (2018), «The Heroikos of Philostratus: A Novel of Heroes, and more», a Cultural Crossroads in the ancient novel, Futre Pinheiro, M., Konstan, D. i MacQueen, B. D. (eds.), Berlin-Boston, De Gruyter, 107-122.

MESTRE, F. (1997), «Retórica y diálogo contra el Sirio», Synthesis, 4, 21-31.

Montandon, A. (ed.) (1999), Écrire la danse, Clermont-Ferrand, Presses Universitaires Blaise Pascal. 
PARISIER-PlotTel, J. (1960), Les Dialogues de Paul Valéry, Paris, PUF.

SAÏD, S. (2015), «La Double Accusation. Une introduction au dialogue lucianesque», a Formes et genres du dialogue antique, Dubel, S. i Gotteland, S. (ed.), Bordeaux, Ausonius, 179-196.

SÉCHAN, L. (1930), La danse grecque antique, Paris, De Boccard.

Serra Arús, E. (2017), Paul Valéry. Diálogo del árbol, Palma de Mallorca, José J. Olañeta Editor.

SYSON, A. (2009), «Born to speak: Ingenium and Natura in Tacitus's Dialogue on Orators», Arethusa, 42, 45-75.

VALÉRY, P. (1957-1960), CEuvres, 2 vols., Paris, Galimard (Bibliothèque de la Pléiade). VALÉRY, P. (1973-1974), Cahiers, 2 vols., Paris, Gallimard (Bibliothèque de la Pléiade). WHITMARSH, T. (2009), "Peforming heroics: language, landscape and identity in Philostratus' Heroicus», a Philostratus, Bowie, E. i Elsner, J. (eds.), Cambridge-New York, Cambridge University Press, 205-229. 